v.10, n.3

Vitória-ES, Jul.-Sep. 2013

p. $130-155$ ISSN 1808-2386 DOI: http://dx.doi.org/10.15728/bbr.2013.10.3.6

\title{
A Study on life microinsurance in Brazil
}

\author{
Karina Reis Silva ${ }^{+}$ \\ Tokio Marine Seguradora \\ Luís Eduardo Afonso ${ }^{\Omega}$ \\ University of São Paulo
}

\begin{abstract}
This study examines the feasibility of life microinsurance in Brazil. Microinsurance is aimed at people with per capita income of up to two minimum wages (MW), according to the definition made by the Brazilian government's agency for superintending private insurance (SUSEP). The main source of data was the Brazilian National Household Survey (PNAD) from year 2008. The target population consists of 41 million family heads. For microinsurance coverages for death and funeral expenses, monthly premiums would range from US\$0.36 to US\$4.13 for those with per capita income of less than $0.25 \mathrm{MW}$. For the income range between 1 and 2 MW per capita, premiums vary between US\$1.32 and US\$15.21. The potential yearly market is approximately US\$1.8 billion, with a potential profit of approximately US\$274 million. These results provide significative evidence that life microinsurance can offer protection for low income people and also can be feasible in Brazil.
\end{abstract}

Keywords: Microinsurance; life insurance; Brazil.

Received 03/15/2011; revised 09/17/2012; accepted 09/30/2012; published 09/30/2013.

*Corresponding Authors;

t. Graduate in Ciências Atuariais from the University of São Paulo

Institution: Tokio Marine Seguradora

Address: Rua. Rua Sampaio Viana, 45 Paraiso,

São Paulo - SP - Brazil

E-mail: katuaria@gmail.com

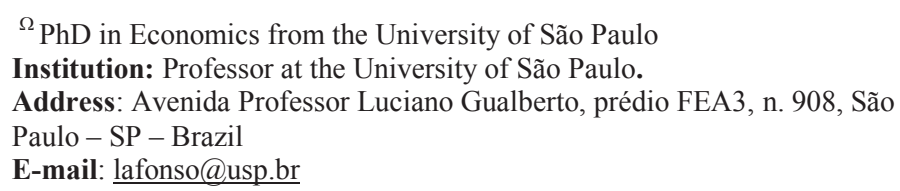




\section{INTRODUCTION}

he Brazilian insurance market has grown considerably in recent years; in fact, there was an annual real increase in premium volume of $9.5 \%$ in 2008. However, despite this growth, the insurance sector still represents only $3.3 \%$ of the country's gross domestic product (GDP) (Fundación Mapfre, 2009). Most insurance business is concentrated in two groups: (i) car insurance policies, which represent $29.6 \%$ of the total; and (ii) $V G B L$ (a type of private pension plan) products, which correspond to $34.5 \%$ of the total.

According to article 757 of the Brazilian Civil Law, insurance is defined as a contract through which "the insurer assumes the obligation, through the payment of a premium, to guarantee the insured's legitimate interest, related to the person or thing, against predetermined risks". The insurance premium is calculated on the basis of the risk involved in the contract. This risk depends on a range of factors - such as the insured's age, housing, and marital status, among others.

Most risks can affect economic agents in different ways. In particular, low-income people tend to be more vulnerable to some risks; moreover, their financial situation often means that they are unable to insure themselves against significant risks. From a social perspective, this situation can be problematic because it means that a particularly vulnerable subgroup of the population lacks basic financial protection against death or invalidity from certain catastrophic events, such as droughts, floods, collapses, and so on (Dercon et al., 2008). A similar view has been suggested, presenting the notion of microinsurance as one of the risk management tool, in the pioneering work by by Siegel, Alwang, Canagarajah (2001). A similar view had previously been expressed by Townsend (1995), albeit without mentioning the precise term microinsurance.

Although there is no single agreed definition of 'microinsurance', its objective is to reach the low-income public by offering insurance policies with lower premiums and more rapid payouts than are available under traditional policies. It is normally offered to people who do not have access to conventional insurance policies (such as informal workers), which usually live in greater vulnerability conditions. The verification of this vulnerability and the inefficiency of more primitive risk management techniques (such as neighbours' assistance in the poorest regions) was one of the factors motivating the development of microinsurance in many countries. 
Also, the target public of microinsurance can be defined by exclusion: these families or people whose income is so low that they are excluded from standard insurance markets. However, many people in the target population of microinsurance are not in such extreme poverty that they fit into social assistance and income-transfer programs (Churchill, 2006).

In contrast to the rest of the Brazilian insurance sector, microinsurance has not yet been fully regulated, although legislation to this effect was under consideration at the time of writing. Despite the lack of formal regulation, microinsurance is acknowledged as part of the Brazilian government's policy on 'microfinance', which aims to provide loans and other financial services for low-income people., aimed at facilitating and expanding credit among formal and informal micro-entrepreneurs and access to financial services for the low-income population, as well as to increase the number and participation of credit cooperatives in the financial system and to decrease informality and interest rates in financing.

Discussions on this policy in 2003 gave rise to the term 'popular insurance' to designate mass products with low insured amounts and premiums. In 2006, SUSEP (the Brazilian government's agency for regulating private insurance) became a member of the International Association of Insurance Supervisors Consultative Group to Assist the Poorest (IAIS-CGAP), which addresses various initiatives, including microinsurance. This was seen as an important step for the development of microinsurance in Brazil.

In parallel with these regulatory developments, the Brazilian economy went through a combination of factors has occurred in recent years that may be unparalleled in the country's recent history, e. g. a prolonged period of low inflation, GDP growth of around 5\% (except in 2009, due to the global financial crisis), and the expansion of income-transfer programs like Bolsa Família. These macroeconomic developments have been associated with an increase in the real income of low-income families, which has raised the demand for consumption goods and insurance products. Despite these positive developments, there are doubts about the status of the market for microinsurance; indeed, it is uncertain whether the product is actually feasible.

In view of this background, the objective of this study is to ascertain the feasibility of life microinsurance in Brazil. In accordance with Vaughan and Vaughan (2007), feasibility is assessed in this study in terms of: (i) the demand side (whether the premium to be paid is appropriate in terms of the consumers' income); and (ii) the supply side (whether the product is profitable for the companies offering it). In other words, the study calculates the life 
microinsurance premiums for some coverages offered. On the basis of these premiums and the number of potential consumers, the potential market size is obtained.

The remainder of the paper is organised as follows. The next section presents the theoretical background for the study, including the definitions of microinsurance and an overview of microinsurance around the world and in Brazil. In the third section, the research methodology is described. In the fourth section, the results of the analyses are presented, including an assessment of the feasibility of the proposed microinsurance products. In the fifth section, the results are subjected to a sensitivity analysis in which two other life mortality tables are used. Finally, in the last section, the conclusions are presented.

\section{LITERATURE REVIEW AND THEORETICAL FRAMEWORK}

\subsection{DEFINITIONS}

According to ILO (2009), the term microinsurance appeared in the literature for the first time in the 1990s, derived from the microfinance, with which it shares a similar target public. Because microinsurance is a relatively recent concept, there is, as yet, no consensus on a single definition of the term. Nevertheless, several descriptions and definitions of the concept have been offered in the literature. According to Chandani (2008, p. 5), microinsurance is the delivery of insurance services to people of low income who usually do not have access to insurance policies or adequate social security services. The Consultative Group to Assist the Poorest Working Group on Microinsurance (CGAP) has provided the following definition, as quoted by Churchill (2006, p. 12): "Microinsurance is the protection of low-income people against specific perils in exchange for regular premium payments proportionate to the likelihood and cost of the risk involved."

According to that same author, microinsurance can be analyzed from two perspectives. One is focused on social protection for the poor in the absence of adequate governmental programs, attempting to diminish social inequality. The other is by offering a financial service to low-income families through the development of an appropriate business models that allow the low-income population to become a profitable market segment for insurance companies and cooperatives. One of the most accepted definition was proposed by IAIS-CGAP (2007, p. $10)$ :

\footnotetext{
Microinsurance is insurance that is accessed by the low-income population, provided by a variety of different entities, but run in accordance with generally accepted insurance practices (which should include the Insurance Core Principles). Importantly this means that the risk insured under a microinsurance policy is managed based on insurance principles and funded by premiums. The microinsurance activity itself should therefore fall within the purview of the relevant
} 
domestic insurance regulator/ supervisor or any other competent body under the national laws of any jurisdiction.

IAIS-CGAP (2007) also defined the target public of microinsurance as: (i) low-income families; (ii) people working in the informal sector of the economy; and (iii) low-income workers from the formal sector. The nature of this definition reveals some degree of overlapping among these three groups.

All definitions presented emphasize microinsurance as a tool that can be used to increase social protection, targeting the low-income population. To fulfill these purposes, it is apparent that microinsurance premiums should be much lower than traditional insurances. In addition, there is a need for close proximity between the consumer and sales channels because a significant proportion of the business conducted by low-income people is conducted in person. This need for close proximity requires the use of alternative distribution channels that are convenient for the target population - such as supermarkets, community leaderships, betting shops, and so on. One example is a microinsurance sold by the South African insurance company Hollard. This company sells a funeral microinsurance, with additional coverages for death and accidents, at supermarket counters in poor regions. For coverages around US\$1,600 for each of these risks, the total premium is less than US\$ 8 per month.

\subsection{MICROINSURANCE AROUND THE WORLD}

Although it is a relatively recent concept, microinsurance is now well disseminated around the world. In many countries, microinsurance models are already an integral part of the implementation process of a comprehensive social protection system (Jacquier et al., 2006). Indeed, according to Roth, Mccord; Liber (2007), only 23 of the 100 poorest countries in the world do not have microinsurance programs. Despite this growth, among the 77 countries that do have such programs, only two have more than 21 providers (India and Mali), two have between 11 and 21 providers, and 73 have fewer than 11 providers (Roth Mccord; Liber, 2007).

In Central and South America, 7.8 million people (representing about 10\% of the entire population) are covered by microinsurance; the majority of these, 6.7 million people, are from Colombia and Peru (Roth, Mccord; Liber, 2007). In Peru, most of the microinsurance is conducted through credit unions and relates to life insurance (more than 3.3 million); in Colombia, most of the life insurance policies (2.5 million) are linked to an entity that also offers funeral insurance. In Africa, microinsurance is quite limited, corresponding to a mere $4 \%$ (3.5 million) of all lives insured of the 100 poorest countries in the world. Moreover, 
approximately 1.6 million of those insured are living on less than US\$2 per day. (Roth, Mccord; Liber, 2007).

Most of the lives insured by microinsurance in the 100 poorest countries come from Asia, which includes more than 67 million lives insured, approximately 58 million of whom live on less than US\$2 per day (Roth, Mccord; Liber, 2007). The majority (more than 58 million) is concentrated in India (more than 30 million) and China (more than 28 million). Nevertheless, more than $97 \%$ of poor people in Asia do not have any kind of microinsurance coverage.

Table 1 provides a summary of these data. Of the products traded in the three regions (Americas, Africa and Asia), a majority relates to life insurances (Roth, Mccord; Liber, 2007).

TABLE 1: NUMBER OF INSURANCE POLICIES PER PRODUCT AND REGION

\begin{tabular}{lcccc}
\hline Region & Life & Health & Accidents and Disability & Property \\
\hline Americas & $7,545,057$ & 445,876 & 105,000 & 600 \\
Africa & $2,036,141$ & $3,053,778$ & $1,603,000$ & $1,600,000$ \\
Asia & $54,158,332$ & $31,697,038$ & $39,180,508$ & $34,557,434$ \\
\hline Total & $63,739,530$ & $35,196,692$ & $40,888,508$ & $36,158,034$
\end{tabular}

Source: Roth, Mccord; Liber (2007)

Various authors have studied creative examples of rural microinsurance in Asia. These include: Cai et al. (2009), who studied microinsurance in China; Giné, Townsend; Vickery (2008) and Manuamorn (2007), who studied rural insurance in India, where farmers are indemnified against rains being above or below certain levels; Goldberg and Ramanathan (2008), who published a review on Latin America; and Matul et al. (2010) who conducted a similar review of microinsurance in Africa. More recently Churchill and Matul (2012) presented an entirely new version of their classical work, written in 2006, with a comprehensive summary of the new developments in microinsurance.

In addition, two academic studies are worthy of note in Brazil. Néri (2009) made an important contribution by mapping the potential microinsurance market in the country. More recently, Afonso and Sepulveda (2010) presented a pioneering study in which they calculated the premiums and estimated the potential market size for residential microinsurance in the country. 


\subsection{MICROINSURANCE IN BRAZIL}

As noted above, the regulatory framework for microinsurance in Brazil is under construction. A fundamental step in the establishment of an adequate regulatory structure occurred in April 2008, when a Consultative Commission for Microinsurance was established. This commission, which includes representatives from a variety of public and private stakeholders, aims to promote research on microinsurance and advise the CNSP on its technical and operational aspects (SUSEP, 2008).

Shortly afterwards, in June 2008, SUSEP established a Microinsurance Work Group to advise the previously created Consultative Commission. In the group's first partial report (August 2008), the definition and target population for microinsurance was based on the IAIS report (IAIS-CGAP, 2007). The low-income population for microinsurance was defined as follows (SUSEP, 2008, p. 26):

\footnotetext{
Low-income population, for the purpose of microinsurance in Brazil, is the population segment with a monthly per capita income of up to two minimum wages, whose occupational position can be classified in the formal as well as in the informal economic sector.
}

The second partial report (October 2008) identified some barriers to microinsurance in Brazil, as well as noting the laws and standards of the current regulatory structure that might impinge on microinsurance. The Work Group concluded that the existing barriers were not derived from insurance legislation; rather, they derived, from such factors as taxation legislation, from insurance companies' high policy costs, and occupational legislation (SUSEP, 2008). Two other reports were also presented: one on microinsurance stakeholders and their respective roles, and the other on probable microinsurance products and their minimal parameters.

In June 2012, Susep released a set of five long-awaited legal norms (Susep 2012a, 2012b, 2012c, 2012d e 2012e), which described and clarified many features about the microinsurance operations in Brazil. Most doubtless, the more important is Circular 440. This norm defined a somehow surprising change, compared to previous legal regulations, Susep no longer defined low-income population according to their per capita income, as it had been done before. Susep left the definition of the potential consumers to the insurance companies, that are allowed to choose of the following criteria:

a) Demographic: age, income, gender, family size, schooling, occupation, among others; 
b) Geographic;

c) Social aspects (e.g. eligibility for social transfers programs);

d) Economic aspects (specific occcupations);

e) Behavioural aspects (life style, consumer decisions etc);

f) Any combination of the criteria above.

\subsection{LIFE MICROINSURANCE}

The first Brazilian standard to address mass insurance policies directed at low-income people referred to life insurance. Circular letter SUSEP 267/2004 established functioning rules and criteria for operating popular life insurance. This standard defined a maximum limit of US\$5,466 for amount insured in the basic guarantee. In addition, elements of the product's actuarial technical note were defined, such as secondary coverages, specification of rates or pure premiums, statistics used for their definition, rate reassessment criteria, loads, technical provisions, and so on. The standard product characteristics proposed by Circular Letter SUSEP 267/2004 were:

- Death by any cause as basic coverage;

- Funeral aid and basic food aid as additional coverages;

- Maximum insured amount of US\$5,466;

- Issuing of individual certificates for collective insurance policies;

- Encouragement of alternative commercial channels, such as electricity, gas or telephone bills.

It's worth noting that Circular 440, cited above, also defined the ceiling of the insured amount for life insurance. The value for death by any cause is about US\$12,000, in 2012. This figure seems to be overestimated, given the per capita income of low-income population in Brazil, as reported in the next section.

\section{DATA AND METHODOLOGY}

\subsection{SAMPLE AND DATA COLLECTION}

The main information source for the present empirical study comprises microdata from the 2008 National Household Sample Survey (PNAD). This rich research is conducted annually by the Brazilian Institute of Geography and Statistics (IBGE) (except in years when the Demographic Census is held), using a representative sample of Brazilian homes and 
inhabitants. Its goal is to investigate various socio-economic characteristics of the Brazilian population - including education, work, income, housing, health, migrations and so on. PNAD 2008 had collected data from approximately 100,000 Brazilian homes and 400,000 people.

The first step was to ascertain how many people qualified as potential microinsurance consumers. As described in section 2.3, the new Susep regulation (Circular 440) left to the insurance companies the definition of the target audience, based on a broad set of possible criteria. This new regulatory direction highlights a possible trade-off. On the one hand, the insurers will be free to define many taylor-made products for the needs of specific groups of consumers. On the other hand, makes less clear the definition of the potential consumers, based on their income. Given this new outlook, we made a choice to follow the criteria previously defined by Susep, i.e., the target audience for the life microinsurance policies analysed in this paper are the earners of per capita income of two minimum wages or less.

The minimum wage at the time of data collection for PNAD 2008 (September 2008) was BRL415 (equivalent to about US\$227). Four income ranges ( $Y$ ) were defined in terms of MW multiples. This choice is due to the importance of the minimum wage as an indexer for the lowest income ranges and the so-called lighthouse effect (as the definition given by Souza and Baltar, 1982-3) of the MW, even for informal workers. As shown in Table 2, approximately 150 million Brazilians were found to fit into the income range for microinsurance defined by SUSEP.

TABLE 2: BRAZILIAN PEOPLE ELIGIBLE FOR MICROINSURANCE PER MINIMUM WAGE RANGE PER CAPITA

Per capita income $Y$ per MW range $\quad$ Eligible for Microinsurance

\begin{tabular}{lcc}
\cline { 2 - 3 } & Number & \% of total \\
\hline $0 \mathrm{MW}<Y \leq 0.25 \mathrm{MW}$ & $19,081,863$ & 12.72 \\
$0.25 \mathrm{MW}<Y \leq 0.5 \mathrm{MW}$ & $35,422,826$ & 23.61 \\
$0.5 \mathrm{MW}<Y \leq 1 \mathrm{MW}$ & $52,337,317$ & 34.89 \\
$1 \mathrm{MW}<Y \leq 2 \mathrm{MW}$ & $43,165,907$ & 28.78 \\
\hline TOTAL & & 100.00
\end{tabular}

Source: PNAD 2008 - Authors' tabulations

Given that the large majority of traditional insurance consumers earn more than two MW, it was important to ascertain whether significant differences (apart from income) existed between those who were eligible for microinsurance and those who were not. Table 3 presents 
some of the characteristics of these two groups. It is apparent that there were important differences between people eligible for microinsurance and those not eligible, with regard to observable characteristics, such as literacy and race. For example, only $2.65 \%$ of those eligible for microinsurance have studied more than 15 years or more of education, in opposition to $25.84 \%$ of those not eligible. Likewise, a difference can be observed between both categories, with a greater predominance of white people (69.30\%) among those not eligible for microinsurance, against $43.18 \%$ in the eligible group. Another considerable difference refers to the percentage of social insurance, and private pension plan contributors. There was clear evidence that people eligible for microinsurance were less likely to be covered by social protection mechanisms, and thus more subject to risks, than those who were ineligible.

\begin{tabular}{|c|c|c|c|}
\hline \multirow{2}{*}{$\begin{array}{l}\text { TABLE 3: CHARACTERISTICS } \\
\text { MICROINSURANCE } \\
\text { Characteristics }\end{array}$} & \multirow[b]{2}{*}{$\begin{array}{l}\text { Not eligible for } \\
\text { microinsurance } \\
(\%)\end{array}$} & \multicolumn{2}{|c|}{ INELIGIBLE } \\
\hline & & $\begin{array}{c}\text { Eligible for } \\
\text { microinsurance (\%) }\end{array}$ & $\begin{array}{c}\text { Total } \\
\text { population } \\
(\%)\end{array}$ \\
\hline Literate & 93.24 & 79.38 & 82.17 \\
\hline 15 years of education or more & 25.84 & 2.65 & 7.32 \\
\hline White & 69.30 & 43.18 & 48.43 \\
\hline Pension benefit & 15.01 & 8.08 & 9.48 \\
\hline Survivor's benefit & 5.44 & 2.97 & 3.47 \\
\hline Social Security Contributor & 41.56 & 21.12 & 25.23 \\
\hline Private Pension Plan Contributor & 5.96 & 0.63 & 1.70 \\
\hline
\end{tabular}

Source: PNAD 2008 - Authors' tabulations

Table 4 compares the eligible and ineligible groups in terms of occupational status. These statistics refer only to people who were in the economically active population (EAP) that is, employed at the time of data collection for PNAD 2008. It is apparent that the group eligible for microinsurance included a greater proportion of informal workers and a smaller proportion of employers. In addition, the proportion of people with zero income (basically workers for self consumption and non-paid workers) was greater in the target public for microinsurance. 
TABLE 4: OCCUPATION OF PEOPLE ELIGIBLE AND INELIGIBLE FOR MICROINSURANCE

\begin{tabular}{lccc}
\hline Main occupation & $\begin{array}{c}\text { Not eligible for } \\
\text { microinsurance } \\
(\mathbf{\%})\end{array}$ & $\begin{array}{c}\text { Eligible for } \\
\text { microinsurance } \\
(\%)\end{array}$ & $\begin{array}{c}\text { EAP } \\
(\%)\end{array}$ \\
\hline Formal worker & 37.30 & 33.56 & 34.51 \\
Military & 0.53 & 0.20 & 0.28 \\
Civil servant & 13.01 & 4.53 & 6.67 \\
Informal employee & 12.49 & 18.78 & 17.19 \\
Formal household worker & 1.03 & 2.22 & 1.92 \\
Informal household worker & 1.91 & 6.38 & 5.25 \\
Self-employed & 18.69 & 20.75 & 20.23 \\
Employer & 11.36 & 2.17 & 4.49 \\
Worker for own consumption & 0.90 & 5.57 & 4.39 \\
Worker for own use & 0.04 & 0.14 & 0.12 \\
Non-income worker & 2.75 & 5.71 & 4.97
\end{tabular}

Source: PNAD 2008 - Authors' tabulations

Finally, Table 5 shows the size of families in both groups. It is apparent that, on average, the families of people eligible for microinsurance are larger than those of ineligible people. This is in accordance with the common observation that poorer people have a larger number of children. As these families have less access to credit and formal risk protection mechanisms, like the usual products the insurance market offers, this is an evidence of this groups' needs for access to alternative risk protection mechanisms even more, such as microinsurance.

TABLE 5: NUMBER OF FAMILY MEMBERS IN FAMILIES OF PEOPLE ELIGIBLE AND INELIGIBLE FOR MICROINSURANCE

\begin{tabular}{cccc}
\hline Family members & $\begin{array}{c}\text { Not eligible for } \\
\text { microinsurance (\%) }\end{array}$ & $\begin{array}{c}\text { Eligible for } \\
\text { microinsurance (\%) }\end{array}$ & $\begin{array}{c}\text { Total population } \\
(\%)\end{array}$ \\
\hline 1 & 6.90 & 2.94 & 3.74 \\
3 & 24.22 & 14.72 & 16.63 \\
4 & 28.76 & 24.69 & 25.51 \\
5 & 25.33 & 27.73 & 27.25 \\
6 & 9.79 & 16.36 & 15.04 \\
7 & 2.66 & 7.20 & 6.29 \\
8 or more & 0.73 & 3.19 & 2.69
\end{tabular}

Source: PNAD 2008 - Authors' tabulations 


\subsection{DATA ANALYSIS}

\subsubsection{Pricing}

The present study calculated the price of the insurance premium in accordance with the standard insurance pricing process. This process begins with an assessment of the probability of the occurrence of a claim, which is known as the Risk Rate or Mathematical Risk Value) $\left(q_{x}\right)$. By definition, this rate should be sufficient to cover the amounts of the claims occurred in a given period. The Risk Rate is calculated in equation 1 on the basis of average number of claims $N S$ in the portfolio of $N R$ units insured by the company:

$$
q_{x}=\frac{N S}{N R}
$$

This average is subject to statistical error, which produces a 'risk variance'. The greater the risk variance, the greater the probability that a premium will be insufficient to cover the claims that are filed, which could lead place the insurance company in a potentially insolvent situation. It is therefore normal practice to use a coefficient, called Security Margin or Statistical Load $(\alpha)$, to protect the insurance company against oscillations in probable claim events. When this load is incorporated, the Pure Rate (TP) is obtained. This is expressed in the following equation:

$$
T P=q_{x}(1+\alpha)
$$

The next step is to calculate the Commercial Rate (TC). This is calculated on the basis of the Pure Rate, imputing two cost components. The first is the Commercial Load $(\theta)$, which serves to cover administrative and trading expenses and the insurance company's profit margin. The second term is the PIS/COFINS (Employees' Profit Participation Program and Social Contribution on Billings). In insurance operations, this tax is not directly charged on the Commercial Rate, but on the difference between premiums free from Tax on Financial Operations (IOF) and Claims Paid. For life insurances, the PIS/COFINS rate is $4.65 \%$. The Commercial Rate is thus defined by equation 3 as follows:

$$
T C=\frac{q_{x}(1+\alpha)(1-P I S / C O F I N S)}{(1-\theta-P I S / C O F I N S)}
$$

The final phase of the pricing process is the calculation of the Gross Rate (TB). This is calculated by incorporating charges (Encargos) and the Tax on Financial Operations (IOF). The charges include the cost of issuing the policy, registration costs, and additional financing of the premium (interest rates charged when the premium is not paid in cash). In the context 
of microinsurance, which is a mass product directed at low-income consumers, the charges are assumed to be equal to zero. The IOF rate for life insurances is $0.38 \%$. Equation 4 shows the calculation of $T B$ :

$$
T B=(T C+\text { Encargos })(1+I O F)
$$

\subsubsection{Proposed life microinsurance product}

The proposed life microinsurance policy that is the subject of this investigation is in general accordance with Brazilian insurance market practices in offering coverage against Death by any cause and coverage against Funeral costs. The choice of these coverages is based on the risks and profile of low-income families. Normally, these do not have ex-ante adequate formal risk management conditions. This means that, when any relative dies, particularly if this is the bread winner. The remaining family members do not immediately manage to have adequate financial conditions to keep the family financially protected. And, often, they aren't unable to cover funeral-related expenses. This situation is aggravated by the fact that, on the average, low-income families are larger than other families, as presented in Table 5.

The risk rate for both forms of coverage offered, Death by Any Cause and Funeral, the Risk Rate (presented in equation 1) corresponds to the probability of death $q_{x}$; in other words, the probability that a person aged $x$ will not reach $x+1$ years. This probability can be obtained from a standard Mortality Table used in insurance and pension fund markets. In Brazil, the chosen Mortality Table should also be authorized by SUSEP.

To transform the Gross Rate (given by equation 4) into the Gross Premium (PB), which is the amount the insured will actually spend when the microinsurance is purchased, $T B$ is multiplied by the Insured Amount (payout figure) of each coverage: death by any cause $(C M)$ and funeral $(C F)$. The Insured Amount (payout figure) is the amount that the beneficiaries of the insurance policy will be paid if the insured person's death does occur. Thus, equations 5, 6 and 7 present the formulae used to calculate the Gross Premiums, respectively, of death by any cause $(C M)$, funeral $(C F)$, and the sum of all coverages.

$$
\begin{aligned}
& P B_{\text {Death }}=C M \frac{q_{x}(1+\alpha)(1-P I S / C O F I N S)}{(1-\theta-P I S / C O F I N S)}(1+I O F) \\
& P B_{\text {Funeral }}=C F \frac{q_{x}(1+\alpha)(1-P I S / C O F I N S)}{(1-\theta-P I S / C O F I N S)}(1+I O F) \\
& P B_{\text {Total }}=C M+C F
\end{aligned}
$$


As explained above, because this is an insurance for the low-income population, it can be reasonably assumed that neither policy emission costs nor additional financing of the premium will be charged (which are common in mass products such as car insurance policies). For the pricing model of the proposed product, the adopted premises are based on the common practices in the insurance market and current legislation.

\section{RESULTS}

\subsection{MARKET SIZE IN BRAZIL}

The target public of microinsurance in Brazil was defined for the purposes of this study as the number of persons (aged 18 years to 80 years) responsible for a family (or considered as such by other members.of the family) who have a maximum per capita income of two minimum wages or less (according to SUSEP rules). Families with zero income were not included in the calculations. It was assumed that none of the families would purchase more than one life insurance.

Table 6 shows the potential market according to the per capita income ranges $(Y)$, given in multiples of minimum wage (MW). The data show that the size of the market for life microinsurance in Brazil was approximately 41.8 million people.

TABLE 6: TARGET PUBLIC ACCORDING TO PER CAPITA INCOME
\begin{tabular}{lcc} 
(MULTIPLES OF MINIMUM MONTHLY WAGE) \\
\hline Per capita income $\boldsymbol{Y}$ per MW range & Number of people & \% of total \\
\hline $0<Y<0.25 \mathrm{MW}$ & $4,064,694$ & 9.73 \\
$0.25 \mathrm{MW}<Y<0.5 \mathrm{MW}$ & $8,536,205$ & 20.44 \\
$0.5 \mathrm{MW}<Y<1 \mathrm{MW}$ & $15,002,817$ & 35.92 \\
$1 \mathrm{MW}<Y<2 \mathrm{MW}$ & $14,168,678$ & 33.92 \\
\hline TOTAL & $41,772,394$ & 100.00
\end{tabular}

Source: PNAD 2008 - Authors' tabulations

\subsection{PROPOSED PRODUCT PREMIUM - BASELINE SCENARIO}

The Gross Premiums for both were based on what was designated as a Baseline Scenario. In this scenario, in which certain premises were assumed in accordance with the Brazilian insurance market and the characteristics of the target population of low-income families.

In choosing an appropriate mortality table, it was assumed that the mortality of the lowincome population would be compromised by poorer health, fewer years of education, lower income, inadequate housing and so on (Waldron, 2007). A shorter life expectancy than other groups in society was thus expected. The IBGE male table published in 2008 was considered 
the mortality table that best represents the biometrical risk profile of individuals eligible for microinsurance. The choice of this table was in accordance with the practice of the Social Security Ministry, which uses this table to calculate retirement benefits by contribution time.

The Commercial Load $(\theta)$ consists of the administrative expenses $(D A)$, commercial expenses $(D C)$ and profit margin $(M L)$. The average values for the Brazilian insurance market are $19 \%, 28 \%$ and 20\%. These figures were calculated based on data collected in SES - Susep Statistical System. This database contains the balance sheets of all insurers in Brazil. Since life microinsurance is a new insurance product, it is expected that operational costs are higher and profit margin is lower than the market as a whole. We decided to be conservative in our choices. The values adopted for these variables were $20 \%, 30 \%$ and $15 \%$ respectively. The parameter $\theta$, which is given by the sum of $D C, D A$ and $M L$, was thus $65 \%$.

For the Statistical Load $(\alpha), 10 \%$ was adopted. In principle, this parameter should reflect variations in mortality or loss ratios, which could affect the insurance company's result. In addition, it should be reminded that the IBGE mortality table, although the most appropriate available table, might underestimate the mortality of people eligible for microinsurance because this table is calculated on the basis of the entire population's mortality experience (rather than only the low-income population, as in the present study). Table 7 shows the premises of this so-called Baseline Scenario:

\section{TABLE 7: BASELINE SCENARIO}

\begin{tabular}{lc}
\hline Item & Value \\
\hline Probability of death & Mortality Table IBGE 2008 - Male \\
Commercial Load $(\theta)$ & $65 \%$ \\
$\quad$ Trading Expenses $(D C)$ & $20 \%$ \\
$\quad$ Administrative Expenses $(D A)$ & $30 \%$ \\
$\quad$ Profit Margin $(M L)$ & $15 \%$ \\
Statistical Load $(\alpha)$ & $10 \%$
\end{tabular}

Source: Authors' assumptions

An insured amount (payout figure) of US\$546.64 was defined for the funeral coverage $(C F)$, irrespective of income. This figure was based on the assumption that funeral expenses would be similar for all people in the microinsurance target public. In contrast, the insured amount for death coverage $(C M)$ varied with income. This figure was based on the income of the head of a family over a period of six months from the date of death. This figure was calculated for each of the four income ranges (defined according to minimum wage multiples) 
as six times the highest income in each range. These numbers are shown in Table 8. For example, the payout figure in the first line of the table showing an insured amount of US\$ 340.28 for $C M$ was obtained by multiplying 0.25 MW (US\$56.71) by 6 months.

TABLE 8: INSURED AMOUNT FOR DEATH BY ANY CAUSE PER INCOME GROUP

\begin{tabular}{lcc}
\hline $\begin{array}{l}\text { Per capita income } \boldsymbol{Y} \text { per MW } \\
\text { range }\end{array}$ & Insured Capital Formula & Insured Capital (US\$) \\
\hline $0 \mathrm{MW}<Y \leq 0.25 \mathrm{MW}$ & $0.25 \mathrm{MW} \times \mathbf{6}$ & 340.28 \\
$0.25 \mathrm{MW}<Y \leq 0.5 \mathrm{MW}$ & $0.5 \mathrm{MW} \times \mathbf{6} 680.57$ \\
$0.5 \mathrm{MW}<Y \leq 1 \mathrm{MW}$ & $1 \mathrm{MW} \times 6$ & $1,361.13$ \\
$1 \mathrm{MW}<Y \leq 2 \mathrm{MW}$ & $2 \mathrm{MW} \times 6$ & $2,722.26$
\end{tabular}

Source: PNAD 2008 - Authors' tabulations

To avoid an annual increase in premiums with increasing age (given an annual rise in the probability of death of the insured person), five age ranges were defined within the overall span of 18 years to 59 years (or more). In accordance with local Brazilian Statute of the Elderly, no divisions were considered after the age of 60 years. Table 9 shows the number of people per age range and income range. As observed, the number of people in the first age range is smaller than in the other groups. This is the case because it was defined that only heads of family would be considered as the target public, and it is more common for these to be concentrated in the higher age ranges. For each range, the premium to be paid corresponds to the weighted average of the premium calculated in terms of the number of people in each age range.

TABLE 9: NUMBER OF PEOPLE IN MICROINSURANCE TARGET PUBLIC PER AGE RANGE AND MW RANGE

\begin{tabular}{lcccccc}
\hline $\begin{array}{l}\text { Per capita income } \boldsymbol{Y} \text { per } \\
\text { MW range }\end{array}$ & \multicolumn{5}{c}{ Age range (years) } & Total \\
\cline { 2 - 6 } & $\mathbf{1 8}$ to 28 & $\mathbf{2 9}$ to $\mathbf{3 8}$ & $\mathbf{3 9}$ to 48 & $\mathbf{4 9}$ to 58 & $\mathbf{5 9}$ or more & \\
\hline $0 \mathrm{MW}<Y \leq 0.25 \mathrm{MW}$ & 654,729 & $1,342,128$ & $1,138,196$ & 660,262 & 269,379 & $4,064,694$ \\
& & & & & & \\
$0.25 \mathrm{MW}<Y \leq 0.5 \mathrm{MW}$ & $1,268,393$ & $2,385,005$ & $2,164,506$ & $1,474,427$ & $1,243,874$ & $8,536,205$ \\
$0.5 \mathrm{MW}<Y \leq 1 \mathrm{MW}$ & $1,651,988$ & $3,193,176$ & $3,647,305$ & $2,716,008$ & $3,794,340$ & $15,002,817$ \\
$1 \mathrm{MW}<Y \leq 2 \mathrm{MW}$ & $1,482,525$ & $2,678,380$ & $3,381,718$ & $3,016,372$ & $3,609,683$ & $14,168,678$ \\
\hline TOTAL & & & & & & \\
\hline
\end{tabular}

Source: PNAD 2008 - Authors' tabulations

\subsection{RESULTS}

Based on equations 5, 6 and 7, together with the assumptions described above, the Gross Premium for each coverage was calculated. Tables 10-13 show the monthly Gross 
Premiums payable for each of the four per capita income levels. The load percentages and profit margin are assumed to be the same in each age range.

In addition to the monthly premiums payable for each coverage, Tables 10-13 also indicate the number of people eligible for microinsurance and the monthly market potential. For example, in Table 10, the potential demand in the age range between 18 and 28 years was obtained by multiplying the monthly premium of US\$0.43 (for death and funeral coverages) by the number of eligible people $(649,812)$ to obtain a potential market figure of US $\$ 278,506.08$.

TABLE 10: MONTHLY PREMIUMS FOR INCOME RANGE: $0<\mathrm{Y} \leq 0.25 \mathrm{MW}$

\begin{tabular}{|c|c|c|c|c|c|}
\hline \multirow[t]{2}{*}{$\begin{array}{l}\text { Age range } \\
\text { (years) }\end{array}$} & \multicolumn{3}{|c|}{$\begin{array}{c}\text { Premiums per coverage } \\
\text { (US\$/month) }\end{array}$} & \multirow[t]{2}{*}{$\begin{array}{l}\text { Number of } \\
\text { people }\end{array}$} & \multirow[t]{2}{*}{$\begin{array}{l}\text { Potential Market } \\
\text { (US\$/month) }\end{array}$} \\
\hline & Funeral & Death & Death + Funeral & & \\
\hline 18 to 28 & 0,22 & 0,14 & 0,36 & $649.812,00$ & $232.357,60$ \\
\hline 29 to 38 & 0,28 & 0,17 & 0,45 & $1.384 .625,00$ & $626.059,28$ \\
\hline 39 to 48 & 0,46 & 0,29 & 0,75 & $1.213 .399,00$ & $910.166,31$ \\
\hline 49 to 58 & 0,87 & 0,54 & 1,41 & $705.572,00$ & $996.135,62$ \\
\hline 59 or more & 2,54 & 1,58 & 4,13 & $290.311,00$ & $1.198 .239,17$ \\
\hline Total & & & & & $3.962 .957,99$ \\
\hline
\end{tabular}

Source: Authors' calculations

TABLE 11: MONTHLY PREMIUMS FOR INCOME RANGE: $0.25<$ Y $\leq 0.5$ MW

\begin{tabular}{|c|c|c|c|c|c|}
\hline \multirow[t]{2}{*}{$\begin{array}{l}\text { Age range } \\
\text { (years) }\end{array}$} & \multicolumn{3}{|c|}{$\begin{array}{c}\text { Premiums per coverage } \\
\text { (US\$/month) }\end{array}$} & \multirow[t]{2}{*}{$\begin{array}{l}\text { Number of } \\
\text { people }\end{array}$} & \multirow[t]{2}{*}{$\begin{array}{l}\text { Potential Market } \\
\text { (US\$/month) }\end{array}$} \\
\hline & Funeral & Death & Death + Funeral & & \\
\hline 18 to 28 & 0,22 & 0,27 & 0,49 & $1.306 .092,00$ & $646.211,33$ \\
\hline 29 to 38 & 0,28 & 0,35 & 0,63 & $2.423 .379,00$ & $1.516 .129,40$ \\
\hline 39 to 48 & 0,46 & 0,58 & 1,04 & $2.150 .340,00$ & $2.231 .803,21$ \\
\hline 49 to 58 & 0,87 & 1,08 & 1,95 & $1.410 .139,00$ & $2.754 .677,08$ \\
\hline 59 or more & 2,54 & 3,17 & 5,71 & $1.355 .852,00$ & 7.743.261,89 \\
\hline Total & & & & & $14.892 .082,91$ \\
\hline
\end{tabular}

Source: Authors' calculations

TABLE 12: MONTHLY PREMIUMS FOR INCOME RANGE: $0.5 \mathrm{MW}<\mathrm{Y} \leq 1 \mathrm{MW}$

\begin{tabular}{cccccr}
\hline $\begin{array}{c}\text { Age range } \\
\text { (years) }\end{array}$ & \multicolumn{3}{c}{$\begin{array}{c}\text { Premiums per coverage } \\
\text { (US\$/month) }\end{array}$} & $\begin{array}{c}\text { Number of } \\
\text { people }\end{array}$ & $\begin{array}{c}\text { Potential Market } \\
\text { (US\$/month) }\end{array}$ \\
\cline { 2 - 5 } & Funeral & Death & Death + Funeral & & \\
\hline 18 to 28 & 0,22 & 0,55 & 0,77 & $1.604 .146,00$ & $1.233 .825,59$ \\
29 to 38 & 0,28 & 0,69 & 0,97 & $3.282 .901,00$ & $3.192 .874,12$ \\
39 to 48 & 0,46 & 1,15 & 1,61 & $3.550 .197,00$ & $5.728 .096,15$ \\
49 to 58 & 0,87 & 2,17 & 3,04 & $2.662 .604,00$ & $8.085 .826,78$ \\
59 or more & 2,54 & 6,33 & 8,88 & $3.737 .084,00$ & $33.178 .259,80$ \\
\hline Total & \multicolumn{7}{c}{} & & $51.418 .882,44$ \\
\hline
\end{tabular}

Source: Authors' calculations 
TABLE 13: MONTHLY PREMIUMS FOR INCOME RANGE: 1MW < Y $\leq 2 \mathrm{MW}$

\begin{tabular}{cccccr}
$\begin{array}{c}\text { Age range } \\
\text { (years) }\end{array}$ & \multicolumn{3}{c}{$\begin{array}{c}\text { Premiums per coverage } \\
\text { (US\$ /month) }\end{array}$} & \multirow{2}{*}{$\begin{array}{c}\text { Number of } \\
\text { people }\end{array}$} & $\begin{array}{c}\text { Potential Market } \\
\text { (US\$ } / \text { month) }\end{array}$ \\
\cline { 2 - 4 } & Funeral & Death & Death + Funeral & & \\
\hline 18 to 28 & 0,22 & 1,10 & 1,32 & $1.416 .647,00$ & $1.867 .012,74$ \\
29 to 38 & 0,28 & 1,39 & 1,67 & $2.660 .100,00$ & $4.433 .000,00$ \\
39 to 48 & 0,46 & 2,30 & 2,76 & $3.233 .225,00$ & $8.938 .600,59$ \\
49 to 58 & 0,87 & 4,33 & 5,20 & $2.892 .513,00$ & $15.051 .123,86$ \\
59 or more & 2,54 & 12,67 & 15,21 & $3.384 .043,00$ & $51.479 .269,27$ \\
\hline Total & & & & & $81.769 .006,47$ \\
\hline
\end{tabular}

Source: Authors' calculations

As shown in the tables, the premiums quite low - particularly for the lower income ranges and younger ages. It is also apparent that the proportional increase in the premiums was greater than the proportional increase in the person's age, which is a reflection of variation in the pattern of mortality rates. It should also be noted that consumers do not have to purchase both death coverage and funeral coverage. They can choose either (or both) according to their own circumstances and preferences.

On the demand side, given the low premiums, the proposed microinsurance product is likely to be affordable. As such, it can turn into an efficient risk management tool and has the potential to act as a social protection mechanism for more than 41 million Brazilian citizens who would otherwise have difficulty in gaining access to insurance products traditionally offered by the insurance market. This is especially significant because life insurance is not a service that is typically offered by the State, differently from welfare mechanisms like public health, social security and income transfer programs.

Considering all age groups and income grouping, the potential demand (sum of numbers in the last column of Tables 10 to 13) is more than US\$152 million per month. Multiplying this by 12 months, it would seem that there is a considerable potential market of US\$2.2 billion per year. Allowing for a $15 \%$ profit margin (see Table 7), this represents a potential profit of approximately US\$274 million per year. These results suggest that microinsurance of this type could be an attractive product for insurance companies.

In summary, it seems reasonable to conclude based on the presented results, that supply and demand exist for this form of life microinsurance. On these numbers, the product seems to be feasible.

\section{SENSITIVITY ANALYSIS}

Because the risk rate is derived from the mortality rate of the chosen mortality table, the choice of the mortality table is a crucial factor in determining the Commercial Premium $(P C)$. 
The greater the life expectancy, the lower the premium - because the insured person will pay for a longer period. In the baseline scenario described above, the IBGE's male Mortality table was used, which reflects mortality conditions for Brazil in 2008. However, insurance companies typically use the mortality tables elaborated by the Society of Actuaries (SOA), which are based on the demographic pattern of the USA and the accumulated experience of companies in the insurance market. Because the Brazilian experience differs from the American experience, and because this difference increases the possibility of adverse risk rate oscillations, it is therefore important to impute a statistical load percentage in the calculations when using an SOA mortality table. For these reasons, the present study subjected the obtained results to sensitivity analysis by pricing the proposed microinsurance products using two other mortality tables.

In Brazil, where the use of mortality tables in the life insurance business (and also in private pension plans) is regulated by SUSEP, most life insurance premium calculations use the AT-83 Annuity Table, which reflects mortality conditions in the USA in 1983. This table was used for the sensitivity analysis. However, the parameters of this table might not be appropriate for the microinsurance proposed here - because the probabilities of death in the table are always less than those recorded by IBGE in Brazil. Given the socio-demographic characteristics of the eligible population for microinsurance, it was therefore decided that pricing would also be calculated with the AT-49 table, which has mortality rates that are closer to the target public of the product under analysis. Indeed, this latter table was used for various Brazilian insurance products until some years ago.

Table 14 summarises the three scenarios using the three tables noted above (IBGE-2008 male; AT-49; and AT-83). To define the statistical load percentages, allowances were made for potential differences between the mortality rates in each of the tables and the real mortality rates of the target population. For example, the life expectancy in AT-83 is greater because this is a more recent table - thus reflecting advances in housing, nutrition, and health conditions). As a consequence, there is likely to be a greater disparity between this table and the mortality rates in the proposed Brazilian target public. A greater statistical load rate therefore needs to be used to reflect the greater uncertainty associated with the use of this table. 
TABLE 14: THREE SCENARIOS FOR SENSITIVITY ANALYSIS

\begin{tabular}{ccc}
\hline Scenario & Life Table & Statistical load \\
\hline Baseline scenario & IBGE-2008 Male & $10 \%$ \\
Scenario 2 & AT-49 & $15 \%$ \\
Scenario 3 & AT-83 & $20 \%$ \\
\hline
\end{tabular}

Source: Authors' assumptions

In making the calculations, the same methodology was adopted as described above for the 'baseline scenario'. The results for scenarios 2 and 3 for each income band are shown in Tables 15-18. It is apparent that there is little difference in premiums between the baseline Scenario and AT-49, but that there is a much larger differential between the Baseline Scenario and AT-83. This reflects the differences in the tables' mortality rates, particularly in older age groups.

With regard to the potential market size, the figure for scenario 2 was US\$1.64 billion per year and that for scenario 3 was US\$1.04 billion per year. These figures represent annual profits of approximately US\$246 million and US\$156 million, respectively. Despite the considerable variations in the various mortality tables, it would seem that these markets are attractive. Moreover, the monthly premiums remains quite low. In other words, both supply and demand conditions were maintained, even when other mortality tables were used.

TABLE 15: MONTHLY PREMIUMS FOR SCENARIOS 2 AND 3 FOR INCOME

RANGE $0<\mathrm{Y} \leq 0.25 \mathrm{MW}$

\begin{tabular}{|c|c|c|c|c|}
\hline \multirow{3}{*}{$\begin{array}{l}\text { Age range } \\
\text { (years) }\end{array}$} & \multirow{2}{*}{\multicolumn{2}{|c|}{$\begin{array}{c}\text { Scenario } 2 \\
\text { Table AT-49 }\end{array}$}} & \multirow{2}{*}{\multicolumn{2}{|c|}{$\begin{array}{c}\text { Scenario } 3 \\
\text { Table AT-83 }\end{array}$}} \\
\hline & & & & \\
\hline & $\begin{array}{c}\text { Premium } \\
\text { (US\$/month) }\end{array}$ & $\begin{array}{c}\text { Potential Market } \\
\text { (US\$/month) }\end{array}$ & $\begin{array}{c}\text { Premium } \\
\text { (US\$/month) }\end{array}$ & $\begin{array}{c}\text { Potential market } \\
\text { (US\$/month) }\end{array}$ \\
\hline 18 to 28 & 0,10 & $67.251,55$ & 0,09 & $56.451,69$ \\
\hline 29 to 38 & 0,18 & $242.768,65$ & 0,13 & $173.207,81$ \\
\hline 39 to 48 & 0,43 & $517.979,62$ & 0,29 & $355.493,94$ \\
\hline 49 to 58 & 1,24 & $871.799,58$ & 0,75 & $526.805,08$ \\
\hline 59 or more & 4,32 & $1.254 .119,96$ & 2,73 & $791.282,27$ \\
\hline Total & & $2.953 .919,36$ & & $1.903 .240,79$ \\
\hline
\end{tabular}

Source: Authors' calculations 
TABLE 16: MONTHLY PREMIUMS FOR SCENARIOS 2 AND 3 FOR INCOME

RANGE $0.25<\mathrm{Y} \leq 0.5 \mathrm{MW}$

\begin{tabular}{ccccc}
\hline Age range (years) & \multicolumn{2}{c}{ Scenario 2 } & \multicolumn{2}{c}{ Scenario 3 } \\
& \multicolumn{2}{c}{ Table AT-49 } & Table AT-83 \\
\cline { 2 - 5 } & $\begin{array}{c}\text { Premium } \\
\text { (US\$/month) }\end{array}$ & $\begin{array}{c}\text { Potential Market } \\
\text { (US\$/month) }\end{array}$ & $\begin{array}{c}\text { Premium } \\
\text { (US\$/month) }\end{array}$ & $\begin{array}{c}\text { Potential Market } \\
\text { (US\$/month) }\end{array}$ \\
\hline 18 to 28 & 0,14 & $187.033,75$ & 0,12 & $156.998,18$ \\
29 to 38 & 0,24 & $587.913,47$ & 0,17 & $819.457,81$ \\
39 to 48 & 0,59 & $1.270 .128,94$ & 0,41 & $1.456 .807,54$ \\
49 to 58 & 1,71 & $2.410 .842,73$ & 1,03 & $5.113 .424,72$ \\
\hline 59 or more & 5,98 & $8.104 .374,76$ & 3,77 & $8.018 .388,85$ \\
\hline
\end{tabular}

Source: Authors' calculations

TABLE 17: MONTHLY PREMIUMS FOR SCENARIOS 2 AND 3 FOR INCOME RANGE $0.5 \mathrm{MW}<\mathrm{Y} \leq 1 \mathrm{MW}$

\begin{tabular}{|c|c|c|c|c|}
\hline \multirow[t]{3}{*}{ Age range (years) } & \multirow{2}{*}{\multicolumn{2}{|c|}{$\begin{array}{c}\text { Scenario } 2 \\
\text { Table AT-49 }\end{array}$}} & \multirow{2}{*}{\multicolumn{2}{|c|}{$\begin{array}{c}\text { Scenario } 3 \\
\text { Table AT-83 }\end{array}$}} \\
\hline & & & & \\
\hline & $\begin{array}{c}\text { Premium } \\
\text { (US\$/month) }\end{array}$ & $\begin{array}{c}\text { Potential Market } \\
\text { (US\$/month) }\end{array}$ & $\begin{array}{c}\text { Premium } \\
\text { (US\$/month) }\end{array}$ & $\begin{array}{c}\text { Potential Market } \\
\text { (US\$/month) }\end{array}$ \\
\hline 18 to 28 & 0,22 & $357.107,68$ & 0,19 & $299.760,11$ \\
\hline 29 to 38 & 0,38 & $1.238 .109,17$ & 0,27 & $883.352,03$ \\
\hline 39 to 48 & 0,92 & $3.259 .884,49$ & 0,63 & $2.237 .287,25$ \\
\hline 49 to 58 & 2,66 & 7.076.566,92 & 1,61 & $4.276 .179,41$ \\
\hline 59 or more & 9,29 & $34.725 .552,99$ & 5,86 & $21.909 .956,83$ \\
\hline Total & & $6.657 .221,24$ & & $29.606 .535,62$ \\
\hline
\end{tabular}

Source: Authors' calculations 
TABLE 18: MONTHLY PREMIUMS FOR SCENARIOS 2 AND 3 FOR INCOME

RANGE $1 M W<$ Y $\leq 2 \mathrm{MW}$

\begin{tabular}{|c|c|c|c|c|}
\hline \multirow[t]{3}{*}{ Age range (years) } & \multirow{2}{*}{\multicolumn{2}{|c|}{$\begin{array}{c}\text { Scenario } 2 \\
\text { Table AT-49 }\end{array}$}} & \multirow{2}{*}{\multicolumn{2}{|c|}{$\begin{array}{c}\text { Scenario } 3 \\
\text { Table AT-83 }\end{array}$}} \\
\hline & & & & \\
\hline & $\begin{array}{c}\text { Premium } \\
\text { (US\$/month) }\end{array}$ & $\begin{array}{c}\text { Potential Market } \\
\text { (US\$/month) }\end{array}$ & $\begin{array}{l}\text { Premium } \\
\text { (US\$/month) }\end{array}$ & $\begin{array}{l}\text { Potential Market } \\
\text { (US\$/month) }\end{array}$ \\
\hline 18 to 28 & 0,38 & $540.371,83$ & 0,32 & $453.594,05$ \\
\hline 29 to 38 & 0,65 & $1.718 .996,03$ & 0,46 & $1.226 .449,71$ \\
\hline 39 to 48 & 1,57 & $5.086 .996,56$ & 1,08 & $3.491 .250,25$ \\
\hline 49 to 58 & 4,55 & $13.172 .466,85$ & 2,75 & $7.959 .768,09$ \\
\hline 59 or more & 15,92 & $53.880 .043,85$ & 10,05 & $33.995 .410,67$ \\
\hline Total & & $74.398 .875,12$ & & $47.126 .472,76$ \\
\hline
\end{tabular}

Source: Authors' calculations

\section{CONCLUSIONS}

This study has examined the potential market for life microinsurance in Brazil. The study finds that the number of people eligible for life microinsurance - that is, with per capita income of two minimum wages (MW) or less — is approximately 41.7 million family heads. The study has proposed microinsurance products providing coverages for death due to any cause (with insured amounts in accordance with the person's income) and coverage for funeral expenses (with a fixed amount irrespective of income). The study finds that monthly premiums for these products are quite low for those with a per capita income below 0.25 MW-varying from US\$0.36 to US\$4.13 (depending on the age range). For those in the income range between $1 \mathrm{MW}$ and $2 \mathrm{MW}$ per capita, monthly premiums range from US\$1.32 to US\$15.21.

The total potential of the market in the baseline scenario considered here is approximately US\$1.8 billion per year. Assuming a 15\% profit margin, the expected profit for this market can reach US\$274 million per year.

Taken together, these results (the relatively cheap price of the premiums for consumers and the attractive potential profit for insurance companies) suggest that this type of product can be feasible in Brazil.

The study has also examined two other scenarios in which other mortality tables were used. These analyses, which were undertaken to ascertain the sensitivity of the results to 
different mortality standards, indicate that the proposed products continue to be feasible even when different assumptions are made with respect to this key variable in life insurance.

To reach the maximum number of potential consumers, every effort should be made to ensure that the microinsurance products proposed here are offered on a mass scale in a form that facilitates purchase by people of limited income. The role of alternative distribution channels (such as supermarkets, mobile phones, betting shops etc.) should be carefully considered. Future studies in this area could investigate these issues, including examination of appropriate trading and contracting forms specifically for microinsurance.

It is also important to mention one first caveat inherent to the pricing model. There is an implicit assumption that the consumers profile (that will effectively purchase the insurance policy) will be the same as the potential market for the product we propose. However, this may not occur. Eventually individuals with the less desired risk profile may be the more likely to purchase insurance in a classic case of adverse selection. Should this occur, surely the loss ratio would be higher than that calculated, which would reduce the size of the market and would affect negatively the profits of the insurance companies. Thus, incorporating adverse selection may be a promising path for other researchers. It's also necessary to bear in mind that this is an exploratory study. There's a long road ahead. Features such as risk aversion, intertemporal preferences and behavioural changes may also be added to the model, allowing a more precise characterization of risk profile of the consumers. ${ }^{\text {ii }}$

The second caveat is linked to supply side. The main results show some evidence that the life microinsurance product may be feasible for consumers (it seems to be an affordable insurance product) and for insurers (there a potential profitable market). But on the other side, this market is still unexplored at the time this paper was being finalized, what seems to be contradictory. There are two main explanations for this possible puzzle. The first one is the distribution channel: it may be costly to develop efficient and user-friendly channels to reach low-income consumers, particularly in small cities and/or rural areas. The second explanation has its foundations on the regulatory framework. Just in late June, 2012, Susep released the long-awaited legal norms that defined in a more precise way some aspects of the microinsurance market in Brazil. These definitions were a sine qua non prerequisite for Brazilian insurance companies to start selling microinsurance products under the conditions legally defined. It's expected that the market will quickly flourish, in accordance to the main conclusions of this article. 


\section{REFERENCES}

AFONSO, L. E.; SEPÚLVEDA, M. P. V. Comprehensive homeowners microinsurance in Brazil: estimation of pricing and market potential. Latin American Business Review, v. 11, n. 3, p. 199-221, 2010.

CAI, Hongbin et al. Microinsurance, trust and economic development: evidence from a randomized natural field experiment. National Bureau of Economic Research, Working Paper No. 15396, October 2009. Disponível em: <http://www.nber.org/papers/w15396>.

CHANDANI, Taara. Lessons learned and recommendations for donors supporting microinsurance. USAID-CGAP Working Group on Microinsurance, September 2008.

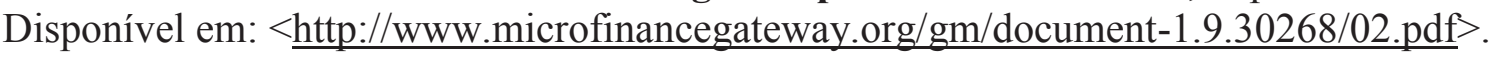

CHURCHILL, Craig (Ed.). Protecting the poor: a microinsurance compendium. Geneva: International Labour Organization, 2006.

CHURCHILL, Craig; MATUL, Michal (Ed.). Protecting the poor: a microinsurance compendium. Vol. II. Geneva: International Labour Organization, 2012.

DERCON, Stefan et al. Literature review on microinsurance. Geneva: International Labour Office, 2008. Microinsurance paper no.1, 33 p.

FUNDACIÓN MAPFRE. The Latin American insurance market 2008-2009. Instituto del Ciencias del Seguro, Fundación Mapfre, 2009.

GINÉ, Xavier; TOWNSEND, Robert; VICKERY, James. Patterns of rainfall insurance participation in rural India. The World Bank Economic Review, v. 22, n. 3, p. 539-566, 2008.

GOLDBERG, Mike; RAMANATHAN, C. S. Microinsurance matters in Latin America. Paper provided by The World Bank in its series World Bank Other Operational Studies with number 10266. Date of creation: nov. 2008.

IAIS-CGAP. Issues in regulation and supervision of microinsurance. [S.1]: IAIS-CGAP Joint Working Group, 2007.

JACQUIER, Christian et al. The social protection perspective on microinsurance. In:

Protecting the poor: a microinsurance compendium, Part I: Principles and practices, I.3, p. 45-64, ILO, 2006

MANUAMORN, Ornsaran Pomme. Microinsurance: the case of weather insurance for smallholders in India. Agriculture and Rural Development Discussion Paper 36. Washington: The International Bank for Reconstruction and Development-The World Bank, 2007.

MATUL, M. et al. The landscape of microinsurance in Africa. Microinsurance Paper $\mathrm{N}^{0} 4$. Geneva: International Labour Organization, 2010.

NERI, M. C. (Coord.) Microsseguros: risco de renda, seguro social e a demanda por seguro privado pela população de baixa renda. Escola Nacional de Seguros (Funenseg) e Centro de Políticas Sociais. Rio de Janeiro: FGV/IBRE, CPS, 2009. 
PNAD - Pesquisa Nacional por Amostra de Domicílios. Síntese de indicadores. Instituto Brasileiro de Geografia e Estatística, 2008.

ROTH, James; MCCORD, Michael J.; LIBER, Dominic. The landscape of microinsurance in the world's 100 poorest countries. Wisconsin: The Microinsurance Centre, LLC, 2007.

SIEGEL, Paul B.; ALWANG Jeffrey; CANAGARAJAH, Sudharshan. Viewing microinsurance as a social risk management instrument. Social Protection Discussion Paper Series No 0116, jun. 2001. Washington: The World Bank, 2001.

SOUZA, P. R. C.; BALTAR, P. E. de A. The minimum wage and wage rates in Brazil. Brazilian Economic Studies, n. 7, 1982-3.

SUSEP - SUPERINTENDENNCIA DE SEGUROS PRIVADOS. Circular SUSEP 267, de 21 de setembro de 2004. Estabelece as regras de funcionamento e os critérios para operação do seguro de vida em grupo popular e disponibiliza, no site da SUSEP, suas condições gerais padronizadas e respectivos parâmetros. 2004.

SUSEP - SUPERINTENDÊNCIA DE SEGUROS PRIVADOS. Circular SUSEP 434, de 19 de abril de 2012. Entrada em vigor da Circular Susep no 432, de 13 de abril de 2012. 2012f.

SUSEP - SUPERINTENDÊNCIA DE SEGUROS PRIVADOS. Circular SUSEP 439, de 27 de junho de 2012. Estabelece as condições para autorização e funcionamento das sociedades e entidades que venham a operar com microsseguro e dá outras providências. 2012a.

SUSEP - SUPERINTENDÊNCIA DE SEGUROS PRIVADOS. Circular SUSEP 440, de 27 de junho de 2012. Estabelece parâmetros obrigatórios para planos de microsseguro, dispõe sobre as suas formas de contratação, inclusive com a utilização de meios remotos, e dá outras providências. $2012 b$.

SUSEP - SUPERINTENDÊNCIA DE SEGUROS PRIVADOS. Circular SUSEP 441, de 27 de junho de 2012. Disciplina a oferta de planos de microsseguro por intermédio de correspondentes de instituições financeiras e demais instituições autorizadas a funcionar pelo Banco Central do Brasil. 2012c.

SUSEP - SUPERINTENDÊNCIA DE SEGUROS PRIVADOS. Circular SUSEP 442, de 27 de junho de 2012. Disciplina a atividade do correspondente de microsseguro. 2012d.

SUSEP - SUPERINTENDÊNCIA DE SEGUROS PRIVADOS. Circular SUSEP 443, de 27 de junho de 2012. Disciplina sobre o registro e a atividade dos corretores de microsseguro. $2012 \mathrm{e}$.

SUSEP - SUPERINTENDENCIA DE SEGUROS PRIVADOS. Portaria SUSEP 2.960, de 12 de junho de 2008. Relatório Parcial I, II, III - Grupo de Trabalho de Microsseguros, 2008.

TOWNSEND, Robert M. Consumption insurance: an evaluation of risk-bearing systems in low-income economies. The Journal of Economic Perspectives, v. 9, n. 3, p. 83-102, 1995.

VAUGHAN, E. J.; VAUGHAN, T. M. Fundamentals of risk and insurance. New York: Wiley, 2007. 
WALDRON, Hilary. Trends in mortality differentials and life expectancy for male social security-covered workers, by average relative earnings. ORES Working Paper Series. Social Security Administration, n. 108, p. 2-61, 2007.

\footnotetext{
${ }^{\mathrm{i}}$ This value is based on information available on the financial statement of one of the three largest insurance companies in Brazil. It's the only large firm that discloses this information. In the Liability Adequacy Test, the firm mentions reports figures between $5 \%$ and $10 \%$.

ii The authors are grateful to one anonymous referee for this suggestion.
} 